\title{
SUBTITUSI SAMPAH ORGANIK DAN TANAH MEDITERAN MENJADI SEMEN ALTERNATIF SELAIN SEMEN PORTLAND
}

\author{
Muhammad Syarif, Victor Sampebulu', Muh.Wihardi Tjaronge, dan Nasruddin Junus \\ Universitas Hasanuddin Makassar \\ Email: muhsyarif00@gmail.com
}

\begin{abstract}
The results of this study aims to save the environment, through the discovery of new alternative materials by recycling organic waste, household waste, coal waste (fly ash and bottom ash), and substitution of mediteran land and clay into organic cement that is alternative cement in addition portland cement. Test results of organic cement chemical compound using laboratory testing method refers to ASTM C-114 and SNI 15-2049-2004. An indication of resembling a portland cement chemical compound is $\mathrm{CaO}$ of $65.36 \%, \mathrm{SiO}_{2} 18.84 \%, \mathrm{AlOO}_{3} 6.33 \%$, $\mathrm{Fe}_{2} \mathrm{O}_{3} 2.29 \%, \mathrm{SO}_{3} 3.64 \%, \mathrm{MgO} 1.35 \%, \mathrm{C}_{3} \mathrm{~S} 66,72 \%, \mathrm{C}_{2} \mathrm{~S} 3.98 \%, \mathrm{C}_{3} \mathrm{~A} 12.9 \%$, and $\mathrm{C} 4 \mathrm{~A} f 6.97 \%$. Test methods of physical properties include testing of baseline time and end time and normal consistency value to organic cement, this test refers to ASTM C 191-04 and C 191-08 and ASTM C 187-04. Fineness of organic cement grains that passed in the mesh 200 mesh as much as 56\%, more subtle than portland cement is 52\%. The solid weight of organic cement is $1200 \mathrm{~kg} / \mathrm{m}^{3}$, lighter than portland cement which reaches $1250 \mathrm{~kg} / \mathrm{m}^{3}$. The initial setting time for organic cement was 105 minutes, longer than portland cement at 90 minutes. For the organic cement final time at 225 minutes, it was above the end time of portland cement at 180 minutes.
\end{abstract}

Keywords: Bottom ash; Fly ash; Mediteran soil; Organic cement; Organic waste; Portland cement.

\begin{abstract}
ABSTRAK
Hasil penelitian ini bertujuan untuk penyelamatan lingkungan, melalui usaha penemuan bahan alternatif terbaru dengan mendaur ulang sampah organik, yaitu limbah sampah rumah tangga, limbah batu bara (fly ash dan bottom ash) serta subtitusi tanah mediteran dan tanah liat menjadi semen organik yaitu semen alternatif selain semen portland. Hasil uji senyawa kimia semen organik menggunakan metode pengujian laboratorium mengacu pada ASTM C-114 dan SNI 15-2049-2004. Dimana telah diperoleh indikasi menyerupai senyawa kimia semen portland berupa: $\mathrm{CaO}$ sebesar $65,36 \%, \mathrm{SiO}_{2}$ $18,84 \%, \mathrm{Al}_{2} \mathrm{O}_{3} 6,33 \%, \mathrm{Fe}_{2} \mathrm{O}_{3} 2,29 \%, \mathrm{SO}_{3} 3,64 \%, \mathrm{MgO} 1,35 \%, \mathrm{C}_{3} \mathrm{~S} 66,72 \%, \mathrm{C}_{2} \mathrm{~S} 3,98 \%, \mathrm{C}_{3} \mathrm{~A} 12,9 \%$, dan $\mathrm{C}_{4} \mathrm{Af}$ $6,97 \%$. Metode pengujian sifat fisis meliputi pengujian waktu ikat awal dan waktu ikat akhir serta nilai konsistensi normal terhadap semen organik, pengujian ini mengacu pada metode ASTM C 191-04 dan C 191-08 serta ASTM C 187-04. Kehalusan butiran semen organik yang lolos pada ayakan 200 mesh sebanyak $56 \%$, lebih halus dari semen portland yaitu $52 \%$. Berat padat semen organik $1200 \mathrm{~kg} / \mathrm{m}^{3}$, lebih ringan dari semen portland yang mencapai $1250 \mathrm{~kg} / \mathrm{m}^{3}$. Waktu ikat awal semen organik adalah 105 menit, lebih lama dari semen portland yaitu pada menit ke 90 . Untuk waktu ikat akhir semen organik pada menit ke 225, berada di atas waktu ikat akhir semen portland yaitu pada menit ke 180 .
\end{abstract}

KataK: Bottom ash; Fly ash; Sampah organik; Semen organik; Semen portland; Tanah mediteran. 


\section{PENGANTAR}

Tulisan ini merupakan hasil penelitian yang berorientasi terhadap daur ulang sampah dan pemanfaatan limbah yang tidak memberikan banyak konstribusi dalam kehidupan masyarakat selama ini. Sampah adalah barang atau benda yang telah habis nilai manfaatnya dan menimbulkan kesan negatif yang menjadikan sampah dipandang sebagai benda yang harus segera disingkirkan dari halaman rumah apapun caranya, (Wahyuning, 2012). Penanganan sampah organik melalui proses pembakaran dengan furnace pada suhu $700^{\circ} \mathrm{C}$ hingga menjadi abu akan mengandung unsur $\mathrm{CaCO} 3$ 69,7\%, $\mathrm{KCl}$ 12,1\%; $\mathrm{SiO} 23 \%$, $\mathrm{Fe}$ $8,1 \%$, dan Al23\%, sedang abu cangkang kerang mengandung $100 \%$ CaCO (Frieska dan Dyah, 2013). Masalah persampahan tampaknya bukan hal yang sederhana karena sepanjang ada kehidupan manusia permasalahan tersebut akan selalu timbul. Makassar sebagai salah satu kota besar di Indonesia telah memproduksi limbah sampah sebesar $4.000 \mathrm{~m}^{3}$ perhari, (Oktovianus, 2015).

Tanah mediteran adalah tanah yang terbentuk dari pelapukan batuan sedimen dan batuan kapur. Tanah jenis ini memiliki kandungan karbonat yang cukup besar dan kandungan lain yang berupa senyawa besi, air, alumunium, dan beberapa bahan organik lain (Abdi, 2016).

Kebutuhan bahan bangunan perlu disikapi dengan melakukan penelitian untuk pemanfaatan dan penemuan bahan bangunan yang mampu menjadi bahan alternatif. Kajian ekperimental yang telah dilakukan serangkaian dengan hal tersebut adalah mensubtitusi tanah mediteran dan tanah liat dengan limbah melalui sistem daur ulang sampah organik yaitu limbah sampah rumah tangga, limbah batu bara (fly ash dan bottom ash) untuk menjadi semen organik, yaitu semen alternatif terbaru selain semen portland. Peningkatan kebutuhan akan perumahan maupun infrastruktur secara otomatis menuntut kebutuhan akan bahan bangunan yang semakin meningkat pula. Peningkatan akan kebutuhan bahan bangunan harus disikapi dengan pemanfaatan dan penemuan bahan bangunan yang mampu memberikan alternatif.

Semen yang mengandung unsur mineral sebagai pengganti sebagian semen portland dikenal sebagai semen komposit, semen campuran atau semen alternatif. Komponen mineral yang ditambahkan disebut mineral tambahan yang bersifat reaktif dan berkontribusi terhadap proses hidrasi proses. Penggunaan fly ash jenuh merupakan salah satu cara untuk mengurangi penguapan tinggi dalam proses hidrasi terhadap kepadatan semen dalam beton (Sampebulu' Victor, 2012). Semen organik merupakan semen alternatif terbaru selain semen portland yang merupakan kajian ekperimental yang telah dilakukan sebagai bentuk pemanfaatan daur ulang sampah organik (Muhammad $d k k$., 2017).

Semakin besar persentase abu terbang hidrasi, maka waktu pengikatan awal maupun akhir semakin lambat. Senyawa-senyawa C3S, C2S, C3A, dan C4AF akan bereaksi dengan air yang diawali dengan senyawa C3A. Hasil reaksi akan bereaksi kembali dengan unsurunsur utama yang terdapat pada abu terbang yaitu silika dan alumina, maka rantai reaksi hidrasi akan semakin panjang yang pada akhirnya akan menambah waktu pengikatan beton. Semakin besar kandungan abu terbang sebagai pengganti sejumlah semen pada adukan beton maka senyawa-senyawa C3S, C2S, C3A, dan C4AF akan berkurang pula hal ini akan menyebabkan berkurangnya panas hidrasi. Berkurangnya panas hidrasi akan memperlambat reaksi sehingga akan memperlambat waktu pengikatan (Sebayang dkk, 2012).

Abu terbang batubara (fly ash) butirannya berdimensi sangat halus yang lolos pada saringan \#200. Jenis ini mengandung $\mathrm{SiO} 2$, $\mathrm{Al} 2 \mathrm{O} 3, \mathrm{P} 2 \mathrm{O} 5$, dan $\mathrm{Fe} 2 \mathrm{O} 3$ namun kandungan $\mathrm{SiO} 2$ cukup tinggi mencapai \pm 70 persen. Dengan kandungan silika yang cukup tinggi memungkinkan abu batubara memenuhi kriteria sebagai bahan yang memiliki sifat semen/pozzolan (Tumingan dkk, 2016). Penggunaan fly ash membentuk pengurangan emisi polusi udara yang dampak negatifnya 
terhadap perekonomian, telah diamati bahwa 0,9 ton CO2 diproduksi perton produksi semen. Selain itu, komposisi semen adalah $10 \%$ dari berat dalam satuan kubik beton. Dengan demikian penggunaan fly ash memungkinkan untuk mengurangi emisi CO2 di atmosfer sebagai bentuk teknik ramah lingkungan, (Chirag dkk, 2014). Pengaruh penambahan fly ash dengan ukuran tertentu akan meningkatkan kekuatan beton (Adrian, 2015).

Dalam menguji dan mengevaluasi sifat kimia konsentrat semen organik ini juga dilakukan suatu kajian perbandingan sifat fisis untuk melihat tingkat pendekatan dan perbedaan antara semen portland dengan semen organik. Pengujian sifat kimia terlebih dahulu dilakukan pada masing-masing bahan baku yang telah diproses dan merupakan pembentuk konsentrat semen organik. Setelah itu dilakukan pengujian terhadap konsentrat semen organik itu sendiri. Untuk memperoleh hasil yang optimal dalam menguji dan mengevaluasi sifat kimia serta sifat fisis konsentrat semen organik tersebut maka digunakan metode pengujian laboratorium berdasarkan acuan American Standard Testing And Material (ASTM) dan Standar Nasional Indonesia (SNI).

Konsenrat semen organik dibentuk dengan memanfaatkan pengelolaan daur ulang limbah sampah organik yaitu limbah sampah rumah tangga, dengan mensubtitusi tanah mediteran, tanah liat, fly ash, dan bottom ash. Gambar 1 menunjukkan proses pembakaran bahan utama semen organik. Pembakaran bahan baku dilakukan di dalam box fire machine yang mampu menahan panas sampai $1800^{\circ} \mathrm{C}$. Pengontrolan suhu pembakaran menggunakan alat thermometer infra red sanfix IT-1500. Untuk menganalisis setting time menggunakan alat vicat dan untuk menganalisis kehalusan menggunakan alat blane. Pemeriksaan senyawa kimia dilakukan pada laboratorium ilmu kimia Fakultas MIPA Universitas Hasanuddin dan untuk mengetahui sifat fisisnya dilakukan pada laboratorium material, struktur, dan konstruksi Fakultas Teknik Arsitektur Universitas Hasanuddin.
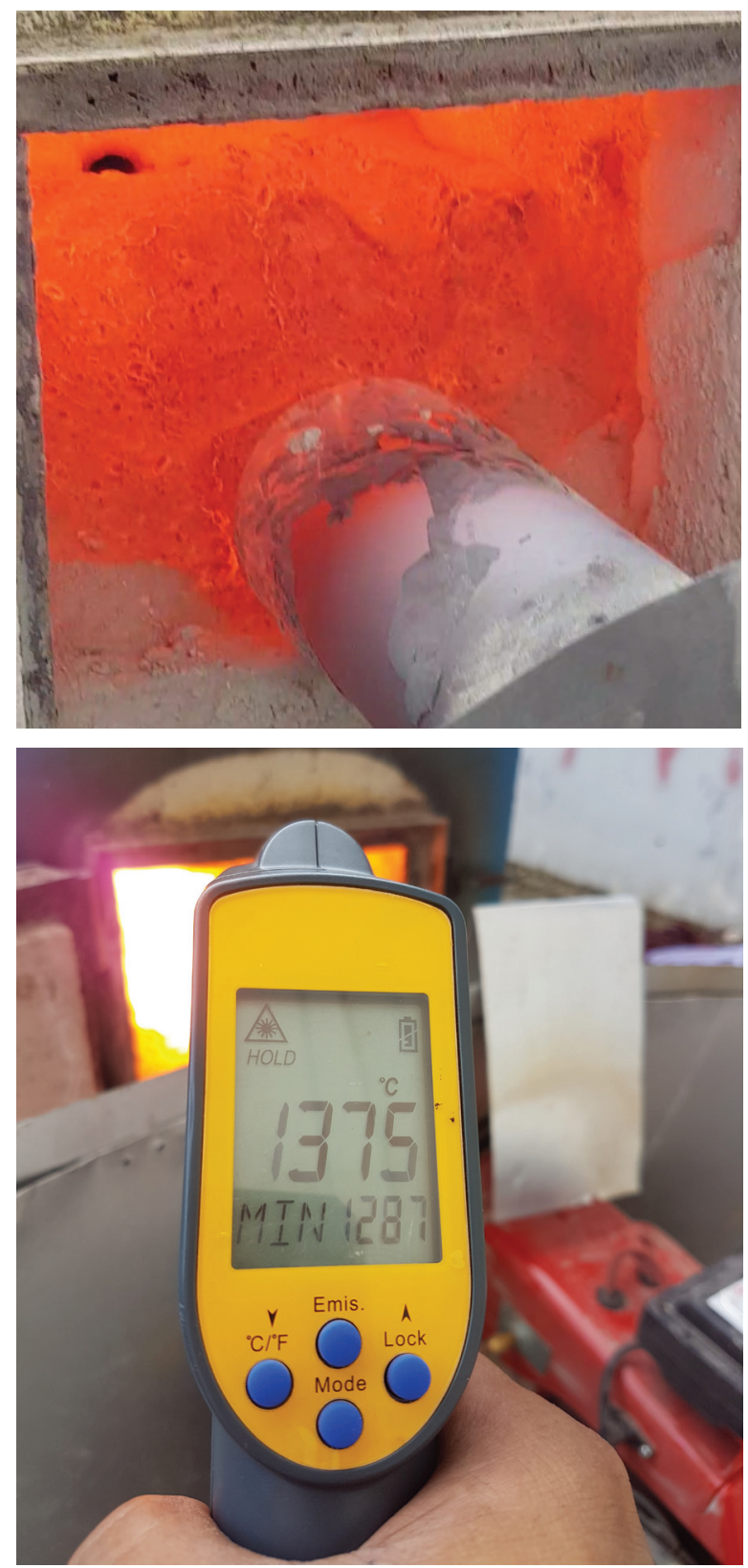

Gambar 1.

Proses Pembakaran Bahan Utama Semen

Organik

Untuk membentuk konsentrat semen organik maka seluruh bahan utama dilakukan proses pembakaran hingga mencapai suhu $1400^{\circ} \mathrm{C}$. Setelah seluruh bahan dibakar selama 4 jam selanjutnya dilakukan pendinginan dan penghalusan. Bahan yang telah berbentuk konsentrat tersebut selanjutnya dilakukan pengujian senyawa kimia untuk melihat pendekatan kelayakan unsur kimianya 
terhadap unsur kimia semen portland dan pengujian sifat fisis untuk melihat kelayakan fisik semen organik berupa kehalusan, berat jenis, waktu ikat awal dan akhir, dan konsistensi normal serta aplikasi terhadap pemakaian pada bangunan yang berupa pengujian beton untuk melihat kelayakan fresh concrete dan hard concrete. Tabel 1 berikut ini menunjukkan proporsi penggunaan bahan utama dan kandungan kimia yang dihasilkan masing-masing konsentrat.

Tabel 1.

Persentasi Bahan Utama Pembentuk semen organik

\begin{tabular}{|c|c|c|c|c|c|}
\hline \multirow[b]{2}{*}{ No } & \multirow[b]{2}{*}{ Jenis bahan utama } & \multicolumn{3}{|c|}{ Komposisi Utama (Besar) } & \multirow[b]{2}{*}{ Unsur kimia Tambahan (kecil) } \\
\hline & & $\begin{array}{l}\text { Unsur Kimia } \\
\text { Utama }\end{array}$ & $\begin{array}{c}\text { Kandungan } \\
(\%)\end{array}$ & $\begin{array}{c}\text { Komposisi } \\
\text { Diambil (\%) }\end{array}$ & \\
\hline 1. & Tanah Mediteran /S & $\mathrm{CaO}$ & 60,93 & 54 & $\mathrm{~S}_{\mathrm{i}} \mathrm{O}_{2}, \mathrm{Al}_{2} \mathrm{O}_{3}, \mathrm{Fe}_{2} \mathrm{O}_{3}, \mathrm{MgO}, \mathrm{SO}_{3}, \mathrm{Na}_{2} \mathrm{O}, \mathrm{K}_{2} \mathrm{O}$ \\
\hline 2. & Tanah Liat / I & $\mathrm{SiO} 2$ & 30,63 & 10 & $\begin{array}{l}\mathrm{SiO}_{2} \mathrm{Al}_{2} \mathrm{O}_{3}, \mathrm{Fe}_{2} \mathrm{O}_{3}, \mathrm{CaO}, \\
\mathrm{Na}_{2} \mathrm{O}, \mathrm{K}_{2} \mathrm{O}, \mathrm{MgO}^{\prime}, \mathrm{SO}_{3}\end{array}$ \\
\hline 3. & Fly Ash / N & $\mathrm{SiO} 2$ & 22,14 & 4 & $\begin{array}{l}\mathrm{Al}_{2} \mathrm{O}_{3^{\prime}} \mathrm{CaO}, \mathrm{Fe}_{2} \mathrm{O}_{3^{\prime}} \mathrm{SO}_{3^{\prime}} \mathrm{Na}_{2} \mathrm{O}, \mathrm{K}_{2} \mathrm{O}, \\
\mathrm{M}_{\mathrm{n}} \mathrm{O}, \mathrm{MgO}, \mathrm{TiO}_{3^{\prime}} \mathrm{P}_{2} \mathrm{O}_{5^{\prime}}, \mathrm{HP}^{2}\end{array}$ \\
\hline 4. & Bottom Ash / A & $\mathrm{SiO} 2$ & 15,20 & 4 & $\mathrm{CaO}, \mathrm{Al}_{2} \mathrm{O}_{3^{\prime}}, \mathrm{Fe}_{2} \mathrm{O}_{3^{\prime}}, \mathrm{MgO}, \mathrm{K}_{2} \mathrm{O}, \mathrm{Na}_{2} \mathrm{O}, \mathrm{HP}$ \\
\hline 5. & Sampah Organik / R & $\mathrm{SiO} 2$ & 46,65 & 28 & $\begin{array}{l}\mathrm{CaO}, \mathrm{Al}_{2} \mathrm{O}_{3^{\prime}}, \mathrm{Fe}_{2} \mathrm{O}_{3^{\prime}} \mathrm{MgO}, \mathrm{K}_{2} \mathrm{O}, \mathrm{TiO}_{2}, \\
\mathrm{Na}_{2} \mathrm{O}, \mathrm{P}_{2} \mathrm{O}_{5}\end{array}$ \\
\hline
\end{tabular}

Rumus empiris kosentrat pembentuk semen organik dapat diturunkan sebagai berikut:

$\frac{\sum \mathrm{R}_{\mathrm{I}} \mathrm{f}=\sum \mathrm{S}+\sum \mathrm{I}+\sum \mathrm{N}+\sum \mathrm{A}+\sum \mathrm{R}}{100}$

Dimana:

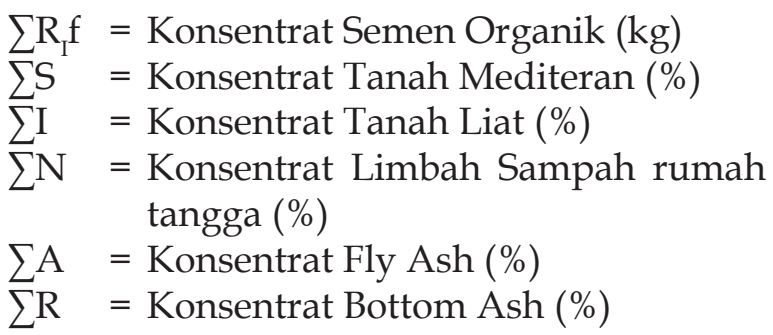

\section{HASIL DAN PEMBAHASAN Unsur kimia}

Penelitian yang telah dilakukan adalah uji senyawa kimia terhadap unsur pembentuk semen organik serta beberapa pengujian sifat fisis berupa kehalusan butiran, berat jenis, berat isi, waktu ikat awal dan waktu ikat akhir semen organik. Hasil analisis sifat kimia konsentrat semen organik sebagai semen alternatif sebagaimana yang ditunjukkan pada tabel 2. Pedoman yang digunakan di dalam pengujian ini adalah ASTM C114 dan SNI 152049-2004. Kedua acuan tersebut merupakan acuan normatif yang dipandang sangat relevan dalam proses pengujian senyawa kimia semen. Pada tabel 3 merupakan kandungan unsur kimia semen portland menurut ASTM C11407. Bahan utama pembentuk semen organik adalah sebagaimana yang ditunjukkan dari hasil pengujian unsur kimia konsentrat, bahan utama tersebut sesuai pada tabel 4, 5, 6, dan 7 yang menguraikan tabel 4 menunjukkan hasil uji senyawa kimia konsentrat sampah organik, tabel 5 merupakan hasil uji senyawa kimia konsentrat tanah mediteran dan pada tabel 6, 7 serta tabel 8 masing-masing adalah hasil uji senyawa kimia konsentrat tanah liat, fly ash, dan bottom ash. Untuk pengujian unsur kimia konsentrat semen organik melalui pengujian XRF (X-Ray Flourencence) dan XRD (X-Ray Difraction). Konsentrat yang telah disiapkan selanjutnya dilakukan uji XRD dan XRF. Hasil uji difraksi sinar-X tersebut kemudian dianalisis kualitatif dengan metode search and match. Analisis menggunakan XRF yang dilakukan berdasarkan identifikasi dan pencacahan karakteristik sinar- $X$ yang terjadi dari peristiwa efek fotolistrik. Efek fotolistrik terjadi karena elektron dalam atom target (sampel) terkena berkas berenergi tinggi (radiasi gamma, sinar-X). Dari hasil analisis tersebut telah diperoleh senyawa kimia semen organik yang berindikasi sebagai suatu 
senyawa yang memiliki pendekatan dengan nilai senyawa yang ada pada semen portland.

Dari semua unsur kimia yang ada pada semen portland maka yang memegang peranan terpenting adalah $\mathrm{C}_{2} 3 \mathrm{~S}_{\mathrm{i}} \mathrm{O}_{5}$ (Alite / $\mathrm{C}_{3} \mathrm{~S}$ $=$ Trikalsium Silikat), $\mathrm{Ca}_{2} \mathrm{~S}_{\mathrm{i}} \mathrm{O}_{5}$ (Belite $/ \mathrm{C}_{2} \mathrm{~S}=$ Dicalsium Silikat), $\mathrm{Ca}_{3} \mathrm{Al}_{2} \mathrm{O}_{6}$ (Aluminate $/ \mathrm{C}_{3} \mathrm{~A}=$ Trikalsium Aluminat), dan $\mathrm{Ca}_{3} \mathrm{Al}_{2} \mathrm{FeO}_{10}$ (Ferrite / $\mathrm{C}_{4} \mathrm{AF}=$ Tetra Kalsium Aluminat Ferri) . Pada semen organik, keempat unsur kimia tersebut telah diperoleh setelah melakukan pembakaran pada tekanan api yang cukup tinggi dan secara terkontrol hingga mencapai suhu $1375^{\circ} \mathrm{C}$ $1400^{\circ} \mathrm{C}$. Hal ini sejalan dengan apa yang telah diuraikan oleh Kimberly (2010). Bahwa empat unsur kimia pada semen potland yaitu $\mathrm{C}_{3} \mathrm{~S}, \mathrm{C}_{2} \mathrm{~S}$, $\mathrm{C}_{3} \mathrm{~A}$, dan $\mathrm{C}_{4} \mathrm{AF}$ diperoleh dari penggabungan unsur kimia mayor komponen yang meliputi $\mathrm{SiO}_{2}, \mathrm{Al}_{2} \mathrm{O}_{3}, \mathrm{Fe}_{2} \mathrm{O}_{3}, \mathrm{CaO}, \mathrm{MgO}, \mathrm{SO}_{3}$, LoI, dan minor komponen yang terdiri dari $\mathrm{Na}_{2} \mathrm{O}, \mathrm{K}_{2} \mathrm{O}, \mathrm{Ti}_{\mathrm{O}} 2$, $\mathrm{P}_{2} \mathrm{O}_{5}, \mathrm{ZnO}, \mathrm{Mn}_{2} \mathrm{O}_{3}$, dan sulfide sulfur. Gambar 2 berikut ini memperlihatkan perbandingan hasil analisis XRD (X-Ray Difraction) antara semen organik dengan semen portland.

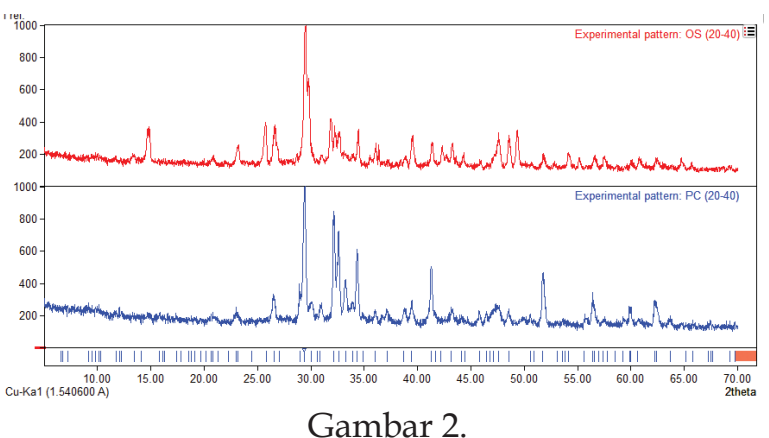

Hasil analisis perbandingan XRD (X-Ray Difraction) semen organik dan semen portland.

Tabel 2.

Unsur kimia semen organik

\begin{tabular}{lll}
\hline \multicolumn{1}{c}{ Parameter } & Satuan & \multicolumn{1}{c}{ Hasil } \\
\hline $\mathrm{C}_{3} \mathrm{~S}$ & $\%$ & 66,72 \\
$\mathrm{C}_{2} \mathrm{~S}$ & $\%$ & 3,98 \\
$\mathrm{C}_{3} \mathrm{~A}$ & $\%$ & 12,9 \\
$\mathrm{C}_{4} \mathrm{AF}$ & $\%$ & 6,9 \\
$\mathrm{LOI}$ & $\%$ & 24,5 \\
$\mathrm{SiO}$ & $\%$ & 18,84 \\
$\mathrm{Al}_{2} \mathrm{O}_{3}$ & $\%$ & 6,33 \\
$\mathrm{Fe}_{2} \mathrm{O}_{3}$ & $\%$ & 2,29 \\
$\mathrm{CaO}_{\mathrm{SO}}$ & $\%$ & 65,36 \\
$\mathrm{Na}_{2} \mathrm{O}+\mathrm{K}_{2} \mathrm{O}$ & $\%$ & 3,64 \\
$\mathrm{MgO}$ & $\%$ & 1,01 \\
\hline
\end{tabular}

Tabel 3.

Unsur kimia semen portland menurut ASTM C114-07

\begin{tabular}{lcc}
\hline \multicolumn{1}{c}{ Parameter } & Satuan & Hasil \\
\hline $\mathrm{C}_{3} \mathrm{~S}$ & $\%$ & $50-70$ \\
$\mathrm{C}_{2} \mathrm{~S}$ & $\%$ & $15-30$ \\
$\mathrm{C}_{3} \mathrm{~A}$ & $\%$ & $5-10$ \\
$\mathrm{C}_{4} \mathrm{AF}$ & $\%$ & $5-15$ \\
$\mathrm{LOI}$ & $\%$ & 1,58 \\
$\mathrm{SiO}$ & $\%$ & 20,60 \\
$\mathrm{Al}_{2} \mathrm{O}_{3}$ & $\%$ & 5,07 \\
$\mathrm{Fe}_{2} \mathrm{O}_{3}$ & $\%$ & 2,90 \\
$\mathrm{CaO}^{\mathrm{SO}}$ & $\%$ & 63,90 \\
$\mathrm{Na}_{2} \mathrm{O}+\mathrm{K}_{2} \mathrm{O}$ & $\%$ & 2,53 \\
$\mathrm{MgO}$ & $\%$ & 0,88 \\
\hline
\end{tabular}

Tabel 4.

Unsur kimia konsentrat sampah organik (sampah rumah tangga)

\begin{tabular}{|c|c|c|}
\hline Parameter & Satuan & Hasil \\
\hline $\mathrm{SiO}_{2}$ & $\%$ & 46,65 \\
\hline $\mathrm{Al}_{2} \mathrm{O}_{3}$ & $\%$ & 2,28 \\
\hline $\mathrm{Fe}_{2} \mathrm{O}_{3}$ & $\%$ & 0,18 \\
\hline $\mathrm{CaO}^{\circ}$ & $\%$ & 11,09 \\
\hline $\mathrm{SO}_{3}$ & $\%$ & 1,01 \\
\hline $\mathrm{Na}_{2} \mathrm{O}$ & $\%$ & 2,24 \\
\hline $\mathrm{K}_{2} \mathrm{O}$ & $\%$ & 11,98 \\
\hline $\mathrm{MgO}$ & $\%$ & 0,02 \\
\hline $\mathrm{P}_{2} \mathrm{O}_{5}$ & $\%$ & 0,47 \\
\hline
\end{tabular}

Tabel 5.

Unsur kimia konsentrat tanah mediteran

\begin{tabular}{|c|c|c|}
\hline Parameter & Satuan & Hasil \\
\hline $\mathrm{SiO}_{2}$ & $\%$ & 60,93 \\
\hline $\mathrm{Al}_{2} \mathrm{O}_{3}$ & $\%$ & 0,44 \\
\hline $\mathrm{Fe}_{2}^{2} \mathrm{O}_{3}^{3}$ & $\%$ & 0,15 \\
\hline $\mathrm{CaO}^{3}$ & $\%$ & 19,35 \\
\hline $\mathrm{SO}_{3}$ & $\%$ & 1,66 \\
\hline $\mathrm{Na}_{2}^{3} \mathrm{O}$ & $\%$ & 0,01 \\
\hline $\mathrm{K}_{2} \mathrm{O}$ & $\%$ & 0,09 \\
\hline $\mathrm{MgO}^{2}$ & $\%$ & 0,018 \\
\hline
\end{tabular}

Tabel 6.

Unsur kimia tanah liat

\begin{tabular}{lll}
\hline \multicolumn{1}{c}{ Parameter } & Satuan & \multicolumn{1}{c}{ Hasil } \\
\hline $\mathrm{SiO}_{2}$ & $\%$ & 30,63 \\
$\mathrm{Al}_{2} \mathrm{O}_{3}$ & $\%$ & 3,41 \\
$\mathrm{Fe}_{2} \mathrm{O}_{3}$ & $\%$ & 0,20 \\
$\mathrm{CaO}$ & $\%$ & 0,51 \\
$\mathrm{Na}$ & $\%$ & 0,01 \\
$\mathrm{~K}_{2} \mathrm{O}$ & $\%$ & 0,23 \\
$\mathrm{MgO}$ & $\%$ & 0,02 \\
$\mathrm{SO}_{3}$ & $\%$ & 0,36 \\
\hline
\end{tabular}


Tabel 7.

Unsur kimia fly ash

\begin{tabular}{|c|c|c|}
\hline Parameter & Satuan & Hasil \\
\hline $\mathrm{SiO}_{2}$ & $\%$ & 22,14 \\
\hline $\mathrm{Al}_{2} \mathrm{O}_{3}$ & $\%$ & 3,84 \\
\hline $\mathrm{Fe}_{2} \mathrm{O}_{3}^{3}$ & $\%$ & 0,20 \\
\hline $\mathrm{CaO}$ & $\%$ & 6,87 \\
\hline $\mathrm{SO}_{3}$ & $\%$ & 0,89 \\
\hline $\mathrm{Na}_{2} \mathrm{O}$ & $\%$ & 0,37 \\
\hline $\mathrm{K}_{2} \mathrm{O}^{\circ}$ & $\%$ & 0,58 \\
\hline MgO & $\%$ & 0,03 \\
\hline
\end{tabular}

Tabel 8.

Unsur kimia Bottom ash

\begin{tabular}{lll}
\hline \multicolumn{1}{c}{ Parameter } & Satuan & \multicolumn{1}{c}{ Hasil } \\
\hline $\mathrm{SiO}_{2}$ & $\%$ & 15,20 \\
$\mathrm{Al}_{2} \mathrm{O}_{3}$ & $\%$ & 2,99 \\
$\mathrm{Fe}_{2} \mathrm{O}_{3}$ & $\%$ & 0,20 \\
$\mathrm{CaO}$ & $\%$ & 1,41 \\
$\mathrm{SO}_{3}$ & $\%$ & 0,15 \\
$\mathrm{Na}_{2} \mathrm{O}$ & $\%$ & 1,03 \\
$\mathrm{~K}_{2} \mathrm{O}$ & $\%$ & 0,17 \\
$\mathrm{MgO}$ & $\%$ & 0,02 \\
\hline
\end{tabular}

\section{Sifat Fisis}

\section{Kehalusan Semen Organik}

Nilai kegemburan/kehalusan bahan untuk semen organik yang lolos pada ayakan 200 mesh sebanyak $56 \%$ dengan berat padat $1200 \mathrm{~kg} / \mathrm{m}^{3}$ sedang untuk semen portland sebanyak $52 \%$ dengan berat padat $1250 \mathrm{~kg} / \mathrm{m}^{3}$. Gambar 2A adalah proses pengujian kehalusan semen organik dan semen portland, sedang gambar 2B proses pengujian berat jenis semen organik. Menurut Kimberly (2010) bahwa berat jenis (specific gravity) semen portland sebesar 3,15 g/ml. Dari hasil analisis ini diperoleh berat jenis semen organik sebesar $3,05 \mathrm{~g} / \mathrm{ml}$. Pengujian berat jenis dalam hal ini mengacu pada rumusan ASTM C 18895. Semakin halus semen maka permukaan butirannya akan semakin luas sehingga persenyawaannya dengan air akan semakin cepat dan membutuhkan air dalam jumlah yang besar pula. Gambar 3A adalah proses pengujian kehalusan semen organik. Gambar 3B merupakan proses pengukuran berat jenis semen organik, sedang gambar 3C adalah konsentrat semen organik yang telah melalui hasil uji senyawa kimia. Dan pada gambar 3D adalah semen portland yang dijadikan sebagai pembanding dalam pengujian sifat fisis. Pada

campuran beton, rasio air terhadap semen didefinisikan sebagai (berat air) / (berat semen) dan sering disingkat w / c. Rasio w / c memiliki pengaruh kuat terhadap kekuatan beton; Untuk campuran tertentu, meningkatkan rasio $\mathrm{w} / \mathrm{c}$ akan menurunkan kekuatan pada semua umur, dan menurunkan rasio $\mathrm{w} / \mathrm{c}$ akan meningkat kekuatan beton (Nicholas, 2014).

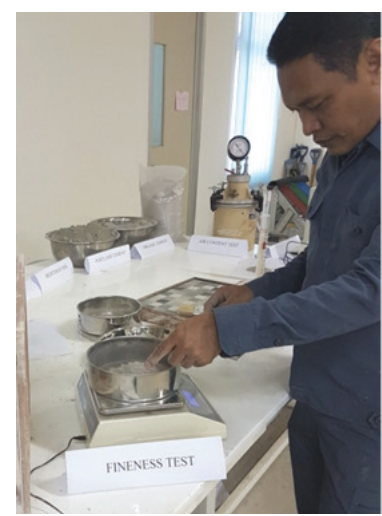

A

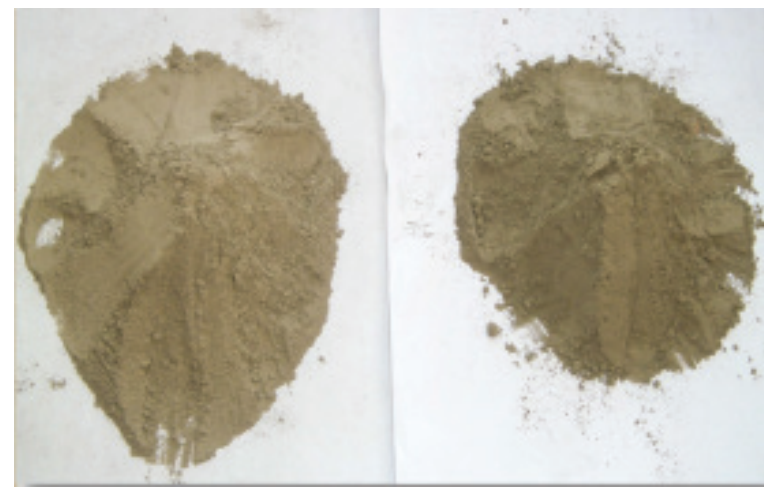

C

Gambar 3

Proses pengujian kehalusan semen organik (A) Proses pengukuran berat jenis semen organik

(B), Konsentrat semen organik (C), semen portland (D).

Pada gambar 4 merupakan silinder beton yang dibuat dari konsentrat semen organik dan semen portland. Gambar tersebut menunjukkan proses pengukuran suhu dan berat benda uji sebagaimana yang diperlihatkan pada bagian A dan B. Pada bagian C dan D merupakan hasil uji tarik belah beton silinder yang telah berumur 28 hari. Rasio air yang tinggi terhadap semen dalam campuran beton adalah salah satu faktor penyebab buruknya kekuatan beton. 


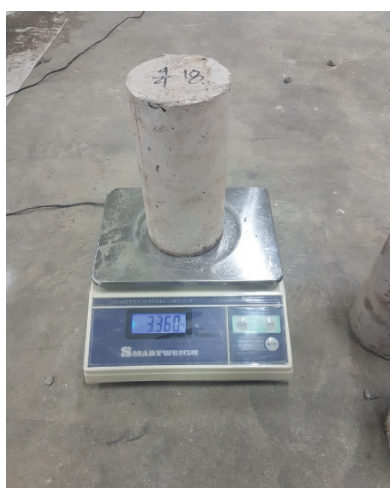

A

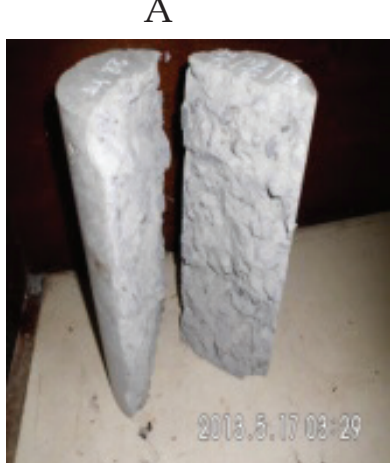

C

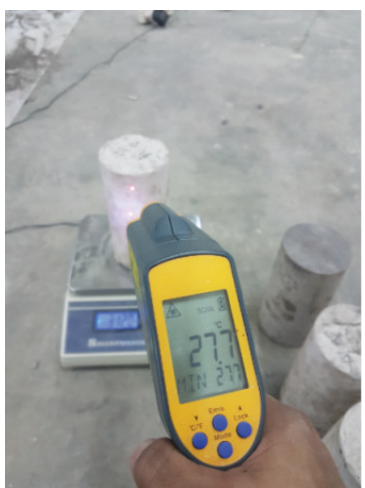

B

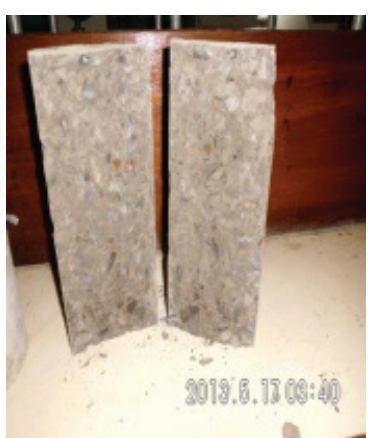

$\mathrm{D}$
Gambar 4

Pengukuran suhu beton silinder dengan semen organik (A), Pengukuran berat beton silinder dengan semen organik (B), Silinder beton semen organik hasil uji tarik belah (C), Silinder beton semen portland hasil uji tarik belah (D)

\section{Setting Time}

Waktu ikat adalah waktu yang diperlukan semen untuk mengeras, terhitung dari mulai bereaksi dengan air dan menjadi pasta semen hingga pasta semen cukup kaku untuk menahan tekanan sebagaimana yang ditunjukkan pada gambar 5. Dalam penelitian ini waktu ikat semen yang ditinjau adalah waktu ikat awal (initial setting) dan waktu ikat akhir (final setting).

Semen yang telah tercampur dengan air atau berada pada suhu lembab menyebabkan terjadinya reaksi kimia berupa pengikatan partikel semen. Waktu yang dibutuhkan oleh semen selama proses pengikatan sesaat setelah terjadi reaksi kimia dengan air atau suhu lembab yang menyebabkan semen menjadi mengeras dan dikatakan sebagai waktu ikat (setting time). Semen yang dibuat dalam bentuk pasta dengan mencampurkan air dan didiamkan beberapa saat hingga pasta semen cukup kaku untuk menahan tekanan sebagaimana yang ditunjukkan pada gambar 4 menyebabkan semen mengalami perubahan bentuk menjadi betuk padat

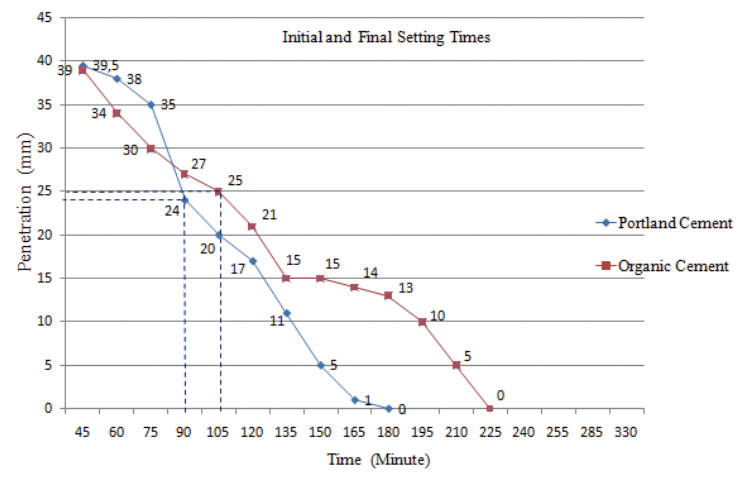

Gambar 5.

Grafik waktu ikat awal dan akhir

Waktu ikat awal dan waktu ikat akhir semen organik serta semen portland diuji dengan metode jarum vicat diameter $1 \mathrm{~mm}$ untuk semen portland yang menembus pasta semen sedalam $24 \mathrm{~mm}$ pada menit ke-90 setelah jarum tersebut dilepaskan. Kadar air yang digunakan untuk pengujian pengikatan adalah kadar air konsistensi normal (25\%). Waktu ikat awal semen organik yang menembus pasta semen sedalam $25 \mathrm{~mm}$ pada menit ke-105 setelah jarum tersebut dilepaskan. Kadar air yang digunakan untuk pengujian pengikatan awal ini adalah kadar air dengan konsistensi normal (37 \%). Menurut standar ASTM C-19108, waktu pengikatan awal tidak boleh kurang dari 45 menit. Waktu pengikatan akhir semen portland berada pada menit ke 180, sedang untuk semen organik berada pada menit ke 225. Menurut standar SNI 03-6827-2002 waktu pengikatan akhir tidak boleh lebih dari 375 menit.

\section{SIMPULAN}

Dari hasil pengujian sifat kimia maupun sifat fisis konsentrat semen organik telah diperoleh indikasi yang menyerupai sifat senyawa kimia semen portland yang dalam hal ini digunakan sebagai sampel pembanding. 
Hal ini dapat dilihat setelah melalui pengujian XRF (X-Ray Flourencence) dan XRD (X-Ray Difraction). Adapun untuk hasil pengujian sifat fisis yang dimiliki semen organik berdasarkan kajian empiris adalah mendekati acuan normatif pada Standar Nasional Indonesia (SNI) dan ASTM.

Berdasarkan hasil uji kelayakan semen organik maka dapat diasumsikan bahwa semen organik sudah dapat digunakan untuk pekerjaan yang bersifat nonstruktur seperti halnya untuk pemasangan tembok bata dan pelesteran tembok. Hal ini ditunjukkan dengan kemampuan semen organik untuk melakukan pengikatan kimiawi terhadap agregat halus sebagai bahan penunjang dalam suatu proses pekerjaan nonstruktur.

Akan tetapi, untuk memperoleh pendekatan kelayakan yang lebih maksimal terhadap semen organik sebagai semen alternatif maka dipandang perlu untuk melakukan kajian eksperimental lanjutan agar kualitas semen organik dapat sesuai dengan yang diharapkan berdasarkan acuan American Standard Testing And Material (ASTM) dan Standar Nasional Indonesia (SNI) sehingga pada akhirnya permasalahan sampah dan usaha penyelamatan lingkungan dari penumpukan limbah sampah sudah dapat terpikirkan penanganannya secara bijaksana melalui pendekatan hasil kajian ekperimental sebagai bahan bangunan alternatif yang dalam hal ini adalah sebagai semen alternatif selain semen portland.

\section{DAFTAR PUSTAKA}

Abdi, M. 2016. “Fungsi Tanah Mediteran Bagi Kehidupan" http://www. majalahbatu.com/2016/ 11/fungsitanah-mediteran-bagi-kehidupan. html (8 November 2016).

Adrian, M.P. et al., Pengaruh Penambahan Abu Terbang (Fly Ah) Terhadap Kuat Tarik Belah Beton. Jurnal Sipil Statik, Vol. 3. No. 11, November 2015: (726-736. ISSN 2337-6732.

American Society for Testing and Material, (ASTM). Designation C 114-07, "Standard Test Methods For of Chemical Analysis of Hydraulic-Cement". P 1-32, Current Edition Approved, July 15, 2007. Published August 2007.
American Society for Testing and Material, (ASTM). Designation C 187-04 Standard Test Normal Consistency Of Hydraulic Cement. Copyright ASTM, PA19428-2959 United states.

American Society for Testing and Material, (ASTM). Designation C 188-95,"Standard Test Methods For Density Of Hydraulic Cement". p 1-2. P 1-2, Current Edition Approved, Sept 10, 1995. Published Nov 1995. Annual book Of ASTM Standards, Vol 14.01-04.02

American Society for Testing and Material, (ASTM). Designation C 191-04,"Standard Test Methods For Time Of Setting Of Hydraulic Cement by Vicat Needle". P 1-10, Current Edition Approved, June 1, 2008. Published July 2008. Annual book Of ASTM Standards, Vol 14.01

American Society for Testing and Material, (ASTM). Designation C 191-08,"Standard Test Methods For Time Of Setting Of Hydraulic Cement by Vicat Needle". P 1-8, Current Edition Approved, June 1, 2008. Published July 2008. Annual book Of ASTM Standards, Vol 14.01

Chirag, Getal., 2014 “Green Concrete Efficient And Eco-Friendly Construction Materials" IMPACT: International Journal of Research in Engineering \& Technology (IMPACT: IJRET), ISSN(E): 2321-8843; ISSN(P): 23474599 Vol. 2, Issue 2, Feb 2014, 259-264

Frieska, A. dan Dyah, S. ((2013) “Studi Eksperimental Pembuatan Ekosemen dari Abu Sampah dan Cangkang Kerang sebagai Bahan Alternatif Pengganti Semen" Juernal Teknik Pomits Vol. 2, No. 2, 2013, ISSN: 2337-3539

Kimberly, K. (2010). Tests on Portland Cement. School of Civil Engineering Georgia Institute of Technology Atlanta, Georgia. (book, page 1-27). 


\section{MUHAMMAD SYARIF, VICTOR SAMPEBULU', MUH.WIHARDI TJARONGE, DAN NASRUDDIN JUNUS \& SUBTITUSI SAMPAH ORGANIK DAN TANAH MEDITERAN MENJADI ...}

Muhammad,Setal.,(2017). “A study OfCement Made From Recycled Gerbage Materials Compared With Portland Cement". The Third International Cenference on Sustainable Infrastructure and Built Environment (SIBE-2017) in Institut Teknologi Bandung (ITB), held on September 26-27-2017.

Nicholas, W. B. "Understanding Cement, Low Concrete Strenght, Ten Potential Cement-Related Causes" Copyright WHD Microanalysis Consultan Ltd. United Kingdom (2014)

Oktovianus. (2015). "Pengelolaan Sampah di Kota Makassar Dengan Bank Sampah". http:/ /artikel-opiniku. blogspot. co.id/2015/08/pengelolaan sampah di kota makassar.html.

Sampebulu' Victor. (2012). "Influence Of High Temperature On The Workability Of Fresh Ready-Mixed Concrete" ITB Engineering, Vol. 44, No. 1, 2012, 2132 ISSN 1978-3051.

Sampebulu' Victor. (2012). "Increase on Strenghts of Hot Weather Concrete by Self-Curing of Wet Porous Aggregat" Civil Engineering Dimension, Vol. 14, No. 2, September 2012, 92-99 ISSN 1410-9530.
Sebayang, S et al., (2012). "Pengaruh Abu Terbang Terhadap Sifat-sifat Mekanik Beton Alir Ringan Alwa". Jurnal Teknik Sipil UBL, Volume 3 Nomor 1, April 2012

Standar Nasional Indonesia,(2004). SNI 152049-2004. Komponen Kimia Semen Portland.

Standar Nasional Indonesia, SNI 03-68272002. Metode Pengujian Waktu Ikat Awal Semen Portland Dengan Menggunakan Alat Vicat.

Tumingan et al., 2016 "Penyerapan dan Porositas Pada Beton Menggunakan Bahan Pond Ash Sebagai Pengganti Pasir" Jurnal Politeknologi Vol. 15 NO. 1 Januari 2016, ISSN 2407-9103

Wahyuning, W. I. (2012) “Pengelolaan Sampah Berbasis "Zero Waste" Skala Rumah Tangga Secara Mandiri" Jurnal Sains dan Teknologi Lingkungan Volume 4 , Nomor 2, Juni 2012, Halaman 101113 ISSN: 2085-1227 